\title{
SEKSUALITAS CYBER: SEX SEBAGAI KESENANGAN DAN KOMODITAS
}

\author{
Puji Rianto \\ Program Studi Komunikasi Universitas Islam Indonesia, Yogyakarta \\ p.rianto1976@gmail.com
}

\begin{abstract}
This paper wants to explore further how sexuality is present in the cyber world. Although the construction of human sexuality age as the man himself, the construction or representation will be largely determined by the social context. Different characters from the cyber world where political authority and the gatekeeper do not contribute significantly will influence the construction of sexuality. The study found that sex is understood as a pleasure and commodities. Various reports of sexual offenders describe how the pleasure of sexual intercourse highly revered. Along with the cult of sexuality as pleasure is sex as a commodity, which is manifested in the form of an offer or advertisement to sell sexual services they provide.
\end{abstract}

\begin{abstract}
Abstrak
Tulisan ini ingin mengeksplorasi lebih jauh bagaimana seksualitas hadir dalam dunia cyber. Meskipun konstruksi seksualitas manusia seumuran manusia itu sendiri, tapi konstruksi atau representasinya akan sangat ditentukan oleh konteks sosialnya. Karakter-karakter yang berbeda dari dunia cyber dimana otoritas politik dan gatekeeper tidak berperan secara signifikan akan mempengaruhi konstruksi atas seksualitas. Studi ini menemukan bahwa seks lebih dipahami sebagai sebuah kesenangan dan komoditas. Berbagai reportasi pelaku seksual menggambarkan bagaimana kesenangan akan hubungan seksual dipuja sedemikian rupa. Seiring pemujaan seksualitas sebagai kesenangan itu, adalah seks sebagai komoditas, yang diwujudkan dalam bentuk berbagai penawaran atau iklan untuk menjual layanan seks yang mereka sediakan.
\end{abstract}

Keywords: Sex, Sexuality, Cyber,

\section{PENDAHULUAN}

Ada yang mengatakan bahwa saat ini kita telah memasuki abad informasi. Namun, ada juga yang mengatakan bahwa kita telah memasuki abad pasca-informasi. Seperti dikemukakan Negroponte (2002: 166), dalam abad informasi, media massa menjadi semakin besar, tapi sekaligus mengecil. Media massa seperti CNN dan USA Today, misalnya, meraih khalayak yang semakin luas dan membuat media tersebut semakin berkembang. Namun, dalam waktu bersamaan, berbagai layanan televisi kabel membuat khalayak media itu semakin spesifik. Sementara itu, abad pascainformasi, menurut Negroponte, ditandai oleh semakin kecilnya khalayak media (narrowcasting) dan permintaan informasi semakin bersifat sangat individual. Di era pascainformasi, kita bergerak dari kelompok besar ke kelompok lebih kecil kemudian semakin 
kecil dan akhirnya individual. Karakteristikkarakteristik media di era pascainformasi ini memungkinkan hal semacam itu terjadi.

Kemunculan media-dalam hal ini internet-telah memberikan suatu isu penting bukan hanya kebutuhan-kebutuhan informasiyangsangatindividualsebagaimana dikemukakan Negroponte. Namun lebih daripada itu, kemunculan internet telah mengubah pola komunikasi massa yang telah begitu dominan selama bertahun-tahun sejak ditemukan mesin cetak Gutenberg. Salah satu bagian pentingnya bahwa di era internet informasi bisa mengalir jauh lebih bebas karena gatekeeper yang biasa dijumpai dalam komunikasi massa tak lagi relevan. Jika komunikasi massa mensyaratkan model komunikasi one to many, maka media baru jauh lebih beragam. Media baru membuat komunikasi bisa mengalir dari one to many, many to many, many to one, dan sebagainya. Perubahan pola komunikasi semacam inilah yang pada akhirnya menciptakan perubahan-perubahan kehidupan manusia, yang salah satu diantaranya dalam hal seksualitas. Seperti dikemukakan oleh Lievrouw dan Livingston, kondisi sosial yang membentuk teknologi komunikasi dibedakan atas dua, yakni rekombinasi dan metafora jaringan. Rekombinasi merujuk pada kelanjutan hibridisasi diantara teknologi media yang sudah eksis dan inovasi dalam jaringan institusional dan teknik yang saling berhubungan satu dengan yang lain (interconnected) (2006: 4). Rekombinasi itu mewujud dalam dua bentuk, yakni konvergen dan divergen yang kesemuanya bisa diobservasi dalam bentuk-bentuk perkembangan media baru seperti bentukbentuk pesan, praktik sosial dan institusi budaya/ekonomi. Sebagai sebuah produk dari siklus kehidupan manusia, media baru akan berada dalam situasi yang selalu terbarukan.

Metafora jaringan digambarkan Castells sebagai "network of networks" (Lievrouw dan Livingston, 2006: 5). Dalam suatu jaringan, keberadaan media baru berbeda dengan media massa. Pada yang pertama, komunikasi lebih bersifat one-to-one dan many-to-many (or n-way), sedangkan yang kedua biasanya lebih bersifat one-to-many. Menurut Lievrouw dan Livingston (2006: 5), pergeseran media baru yang lebih bersifat multiple inilah yang mempunyai implikasi penting dalam manajemen kekuasaan, kepercayaan dan partisipasi dalam hubungan-hubungan sosial, dan kontrol dan difusi informasi.

Media baruatau cyber telah menciptakan banyak pergeseran dalam kehidupan manusia, dan, seperti telah disinggung di awal, seks menjadi salah satunya. Seksualitas dalam dunia cyber telah menabrak begitu banyak dinding ketabuan yang dalam dunia nyata begitu kuat dijaga dan dipelihara. Internet kiranya telah mendapati tuduhan luar biasa sebagai media penyebar nilainilai liberalisasi seks dan pornografi. Sifat radikal media baru telah memberinya peluang bagi munculnya praktik-praktik yang secara moral bertentangan dalam dunia nyata. Maka, dalam dunia baru, dunia cyber, kita mendapati bukan hanya semangat spiritualitas (Zaleski, 1999), tapi juga praktikpraktik yang dikonstruksikan sebagai anti moral. Pornografi, homoseksualitas, pornografi anak, kekerasan, sadisme, dan seterusnya tumbuh dalam ruang media baru tersebut. Dalam dunia cyber, seksualitas, tampaknya, mendapatkan energi yang jauh lebih kuat dibandingkan pada dunia nyata.

Berpijak pada argumentasi di atas, tulisan ini ingin mengeksplorasi lebih jauh bagaimana seksualitas hadir dalam dunia cyber. Asumsinya, meskipun konstruksi seksualitas manusia seumuran manusia itu sendiri, tapi konstruksinya akan sangat ditentukan oleh konteks sosialnya. Oleh karena itu, karakter-karakter yang berbeda dari dunia cyber dimana otoritas politik dan gatekeeper tidak berperan secara signifikan maka konstruksi atas seksualitas akan sangat berbeda dengan dunia nyata. Hipotesis yang diajukan dalam tulisan ini bahwa dunia cyber telah memperkuat konstruksi seks sebagai kesenangan pada satu sisi dan komoditas di sisi lain. Melalui berbagai kombinasi cara (periklanan, reportase, dan pengalaman langsung), seksualitas sebagai kesenangan 
dan komoditas mendapatkan energi yang luar biasa dalam ruang cyber.

\section{METODE}

Untuk menjawab pertanyaan dan secara bersamaan membuktikan hipotesis di atas, studi ini akan mengkaji situs-situs yang dikhususkan untuk pembaca dewasa. Situssitus ini masuk ke dalam 'sensor' pemerintah karena mengandung unsur pornografi dan perjudian. Namun, beberapa situs masih bisa diakses. Dari situs yang bisa diakses inilah, kemudian dicari forum-forum khusus untuk dewasa. Dalam forum dewasa itu, bisanya, ada beragam subforum seperti gambar, cerita dewasa, obrolan dengan anggota lain tentang seks dan topik dewasa lainnya ataupun subforum yang secara khusus menuliskan pengalaman khalayak terkait dengan dunia seksualitas.

Analisis dilakukan secara kualitatif dengan melihat konstruksi atas seksualitas yang dibedakan dalam dua bagian besar, yakni seks sebagai kesenangan dan seks sebagai komoditas. Analisis kualitatif ini akan dipaparkan secara deskriptif dengan mempertajam analisisnya pada konteks teoritik. Dengan begitu, akan didapatkan suatu data dan analisis yang kaya dan mendalam.

\section{HASIL DAN PEMBAHASAN}

Pada umumnya, hubungan seksual sering diasosiasikan dengan pemuasan dorongan biologis yang mendatangkan rasa nikmat dan kesenangan. Di lain pihak, seksualitas dihubungkan pula dengan daya hidup, yaitu pentransformasian energi dalam suatu kegiatan seksual-genital. Seksualitas sering pula dihubungkan dengan kegiatankegiatan yang diberi bentuk 'kultural' dengan seperangkat nilai-nilai yang melatarbelakanginya dalam suatu interaksi sosial sehingga hubungan seksualitas dapat merefleksikan nilai-nilai atau norma-norma yang berlaku dalam suatu masyarakat.

Akibatnya konsepsi seksualitas dalam suatu masyarakat mungkin tidak akan sama dengan masyarakat lainnya. Misalnya praktik-praktik pelacuran dalam suatu masyarakat mendapatkan tantangan dan kutukan, tapi dalam masyarakat lainnya praktik-praktik semacam itu dibiarkan atau bahkan dianjurkan. Hal ini terjadi karena masing-masing masyarakat mempunyai konstruksinya sendiri atas seksualitas dan pelacuran.

Merujuk Weeks (1981), Suriadireja mengemukakan bahwa konstruksi seks pada dasarnya dibentuk oleh sistem kekeluargaan, perubahan sosial dan ekonomi, perubahan aturan-aturan sosial, politik, dan gerakan perlawanan. Dengan kata lain, menurut Suriadireja setiap masyarakat dengan nilainilai budayanya masing-masing mempunyai konsepsi dan konfigurasinya sendiri tentang seksualitas (Purwadi Suriadireja, "Seksualitas dan Ritual di Gunung Kemukus”. http:// ejournal.unud.ac.id/abstrak/kemukus.pdf, hal. 3

Sejarah seksualitas merefleksikan suatu perjalanan penuh konstruksi dan karenanya melibatkan pertarungan kekuasaan yang tak pernah henti. Oleh karena itu, pembacaaan kita atas sejarah seksualitas akan sangat ditentukan oleh rezim-rezim yang berkuasa, yang menang dan yang kalah. Pada masa Yunani dan Romawi, ketelanjangan tidak pernah dipersoalkan sebagai sesuatu yang vulgar atau dosa. Pada masa Romawi ketelanjangan merupakan bagian yang legal dari kehidupan. Baru memasuki abad 18, entitas seks mulai dinormalkan, diregulasi, dan dibuat tidak vulgar (Kadir, 2007: 8).

Di sisi lain seksualitas itu sendiri mengandung dualisme. Pada satu sisi, seks dilihat sebagai sesuatu yang liar dan negatif dalam memperbudak tubuh dan libido semata. Pandangan seks sebagai libidinal dan parsial ini menggiring manusia pada perbudakan tubuh dan nafsu. Sementara di sisi lain, seks dipahami sebagai suatu stimulus spiritual dimana ia demikian dinikmati, sakral dan tabu yang menegangkan (Kadir, 2007: 16). Menurut Kadir, entitas seksualitas yang mendua ini tidak bisa dilepaskan dari perspektif fungsi, yaitu sebagai kenikmatan bernuansa biologis dan sebagai fungsi 
prokreasi bernuansa sosial (Kadir, 2007: 17).

Sebagaimana pula dikemukakan Abramson dan Pinkerton (2002: 4), "kadang kala diargumentasikan bahwa satu-satunya fungsi seksualitas adalah reproduksi. Sebagai akibatnya, ekspresi-ekpresi seksualitas yang tidak diorientasikan untuk tujuan semacam itu dianggap sebagai haram, tidak bermoral, atau tidak logis (illogical)." Meskipun demikian menurut Abramson dan Pinkerton (2002: 5), pandangan bahwa seksualitas semata ditujukan untuk tujuan reproduksi terlalu simplistis. Sebaliknya, kesenangan (pleasure) menjadi kekuatan motivasional di balik prokreasi.

Dalam masyarakat kapitalis, seksualitas bukan hanya persoalan reproduksi dan kesenangan, tapi juga komoditas. Dari sudut pandang feminin, ideologi seksualitas meminjam Janice Winship (2011: 368), bahkan bagi perempuan mengandung unsur yang berlawanan dan kontradiksi, sekalipun terkandung dalam relasi patriarkhal: aktif/ pasif; heteroseksual/narsistik; bergantung pada laki-laki/tidak bergantung pada laki-laki; fetisistik; masturbasi. Menurut Winship, hal ini secara tegas dipisahkan dari 'keibuan' dan 'kerumahtanggaan', yang tidak memungkinkan masuknya seksualitas sekalipun didasarkan pada seksualitas reproduktif.

Seksualitas sebagai komoditas dan juga kesenangan dapat dilihat dalam praktikpraktik pelacuran, yang setua umur manusia. Sebagaimana dikemukakan Kartono (1988), pelacuran atau yang sering disebut dengan prostitusiatau pemuas nafsuseks, merupakan jenis pekerjaan yang setua umur manusia itu sendiri (Bekti Istiyanto, 2008). Menurut Monto dan Julka (2009), "Prostitution is the exchange of something of value, usually money or drugs, for the sexual use of a person's body". Pada akhirnya, menurut Monto dan Julka, melalui komodifikasi seksualitas, kita bisa mengasosiasikan antara frekuensi kunjungan ke tempat prostitusi dengan penerimaan seks sebagai komoditas.

Dalam konteks yang lebih luas, komodifikasi seksualitas sebenarnya mencerminkan komodifikasi atas tubuh (perempuan) dalam masyarakat kapitalis. Dalam hal ini, Nurhadi menulis bahwa tubuh menjadi titik sentral dari mesin produksi, promosi, dan konsumsi kapitalisme. Di sini, tubuh diproduksi sebagai komoditas dengan mengeksplorasi segala potensi hasrat dan libidonya untuk dipertukarkan sebagai komoditas (video girl). Selain itu menurut Nurhadi, tubuh juga dijadikan sebagai metakomoditi yaitu komoditi untuk menjual komoditi lain, melalui peran sentralnya dalam sistem promosi kapitalisme (cover girl); sistem distribusi, yaitu sebagai pendamping komoditas (promo girl); dan juga menjadi sasaran utama dari konsumsi, yakni dengan menciptakan berbagai kebutuhan yang berkaitan dengan tubuh (perfect girl). Begitu sentralnya peran tubuh di dalam masyarakat kapitalisme, menurut Nurhadi, sehingga bersamanya berkembang pesat sains dan teknologi mutakhir tentang penyempurnaan tubuh (body building, operasi plastik) (Nurhadi, 2006).

Dalam duna cyber, seks atau seksualitas dan juga pelacuran menjadi bagian kehidupan manusia yang tak terpisahkan. Konstruksinyalah yang mengalami perubahan atau perbedaan dari suatu masyarakat ke masyarakat lain, dari suatu waktu ke waktu lainnya. Semuanya dipengaruhi oleh konteks sosial dan budaya yang melingkupinya. Oleh karena itu ada suatu masyarakat dengan penuh dendam menghujat seks dan pelacuran, sedangkan lainnya membiarkan atau bahkan menganjurkannya. Semuanya dipengaruhi oleh konteks sosial budayanya, dan juga tentu saja relasi kekuasaan yang bermain dalam proses konstruksi itu. Namun, kedekatannya dengan kehidupan manusia tidak pernah bisa dijauhkan apalagi dilepaskan.

Dalam dunia saiber dimana individu jauh lebih merdeka dan berkuasa atas dirinya dalam akses dan produksi pesan media, konstruksi atas seksualitas jauh lebih terbuka karena individu-individu 'pemuja' kesenangan seksualitas mendapatkan ruangnya. Sementara disisi lain otoritas moral tidak mempunyai perangkat yang memadai untuk menghentikan kelompok-kelompok 
itu. Barangkali mereka bisa menggunakan teknologi untuk melakukan sensor, tapi ada banyak cara untuk mematahkan sensor yang dibuat. Pada akhirnya individual-lah yang mempunyai otoritas tertinggi untuk memilih jenis-jenis pesan macam apa yang dibutuhkan. Ini juga yang terjadi dalam dunia cyber dimana seks menjadi salah satu ikon penting di luar yang lainnya.

\section{Seks adalah Kesenangan, dan Tidak Ada Dosa untuknya}

Wacana semacam ini begitu kuat muncul dalam thread underground service. Kutipan FR (suatu istilah untuk fuck report) di bawah merefleksikan hal dimaksud. Dalam FR yang diberi judul, "Tia, Mahasiswa Putih+ 36B+Seksi”, berkisah tentang pertemuan dua orang teman yang kemudian berlanjut ke hubungan seksual. Dalam paragraft pertama laporan itu, disebutkan sebagaimana bisa dibaca dalam kutipan berikut.

"Beberapa hari yang lalu HP gw berdering.. Dan tak di sangka ternyata temen lama gw menelfon. Namany Tia, doi ngajakin gw ketemu di daerah deket tempat doi. Beberapa hari selalu ada saja halangan untuk bertemu doi. Akhirnya, kemarin, gw punya kesempatan bertemu doi." Kisah itu berlanjut, "Kemudian sambil bercanda-canda doi tiba-tiba mulai mencium gw. Nice kiss. I like how she kiss me...".

Ciuman itupun berlanjut dengan hubungan seksualitas sebagaimana dapat dilihat dalam kutipan berikut yang saya kutip dari akhir paragraf.

..hehehehe gak nyangka ternyata kayak main sama perawan. Trus tw sendiri lah. dari WOT (Woman On TOP, penulis), MOT (Man On Top, penulis), sampai doggie gw coba sm doi. Selesai tempur kita saling senyam senyum..

Ada banyak laporan semacam itu-yang mereka sebut sebagai Fuck Report (FR) yang menunjukkan pengalaman luar biasa menyenangkan dari sebuah hubungan seksual. Tentu saja, pengalaman seksualitas itu tidak hanya berhenti pada hubungan seksualitas dengan teman, tapi juga mencakup hubungan-hubungan seksual dengan panitia training, ibu-ibu rumah tangga, SPG, mahasiswi, pegawai salon atau capster, PNS, dan sebagainya. Laporanlaporan itu merefleksikan kesenangan dan pengalaman luar biasa dalam berhubungan seks, yang secara bersamaan menegaskan moralitas yang begitu dijunjung tinggi oleh masyarakat.

\section{Pengalaman adalah Segalanya}

FR tidak hanya memberikan ekspresi kesenangan seksual, mencerminkan konstruksi para pelaku dalam melihat seksualitas, tapi juga memberikan pengalaman lain bagi anggota komunitas lainnya. Tentu saja tidak hanya pengalaman yang menyenangkan tapi juga yang tidak menyenangkan. Tujuannya agar anggota komunitas lain tidak terjebak pada orang yang sama. Di luar itu pengalamanpengalaman itu bisa menjadi publisitas gratis bagi si penjaja seksual karena dengan begitu anggota komunitas lain bisa 'belajar' atau mendapatkan informasi yang cukup sebagaimenurut bahasa mereka-exe (kependekan dari eksekusi).

Selain pengalaman hubungan seksualitas yang menyenangkan, anggota komunitas yang sering menyebut dirinya -newbiebisa belajar dari senior mereka yang sering diungkapkan sebagai "suhu" untuk belajar mendapatkan pengalaman seksual yang menyenangkan. Istilah SSI (speak-speak iblis) menjadi ungkapan khas bagi para petualang seks yang kantongnya kering. Di sini seorang anggota komunitas bisa belajar dari para "senior" mereka bagaimana cara mendapatkan seorang gadis dan kemudian mengajaknya berhubungan seks. SSI ini menjadi sangat terkenal dalam underground service karena kuatnya pemujaan seksual dari para anggotanya.

Maka pertautan pun menjadi sangat kuat antara realitas dunia nyata dengan dunia cyber. Dunia cyber pada akhirnya adalah rentetan pengalaman-pengalaman para anggota forum dari kegiatan atau aktivitas seksual mereka. Ada sebuah kebanggaan dari para anggota ketika SSI mereka berhasil, 
yang mereka ungkapan dalam serangkaian FR yang mereka tuliskan. Keberhasilan ini akan menjadi suatu poin penting untuk meneguhkan diri mereka sebagai "suhu" dalam dunia yang mereka ungkapkan sebagai "dunia perlendiran." Konstruksi seks dan keriuhan kesenangan di dalamnya adalah hasil dokumentasi paling canggih dari seseorang yang memosisikan dirinya sebagai seorang jurnalis dalam menuliskan pengalaman-pengalaman mereka sendiri ketika melakukan aktivitas seksual. Suatu kesenanganyang mendapatkan pemujaannya dalam taraf yang mungkin mendekati apa yang diungkapkan oleh Roland Barthes sebagai 'plaisir'.

\section{Radikalisasi Pelacuran}

Laporan-laporan lapangan dalam bentuk FRsemacamitu bagaimanapun padaakhirnya mentransformasi sedemikian rupa pelacuran di dunia nyata. Pertama, dalam dunia nyata pengetahuan akan pelacuran didapatkan dari liputan media massa yang sangat dangkal dan permukaan atau dari kekuatan pemasaran mulut ke mulut. Kita mengetahui kompleks pelacuran Doly di Surabaya yang kini sudah tutup ataupun Sunan Kuning di Semarang, Kawasan Baturaden dan sebagainya karena liputan media massa atau dari orang-orang yang pernah cerita. Namun cerita-cerita itu hanya sekilas dan tidak memberikan informasi mendalam. Di sisi lain laporan dari pelaku ketika kita berhadapan muka tidak sejelas dan sedetil mungkin dalam dua cyber. Situasi psikologis komunikasi tatap muka akan menghalanginya untuk bercerita pelaku bercerita lebih detail. Ini sangat berbeda dibandingkan dengan model-model liputan FR underground service. Liputanliputan itu lebih detail dan memberikan banyak informasi termasuk kualifikasi yang diharapkan dari si pekerja seksual. Sebagai contoh, di akhr FR biasanya dicantumkan informasi dan penilaian berikut.

SERVICE:

FK $\quad: 8,5$ (Menggairahkan)

BJ $\quad: 8$ (Sangat telaten E mantap)

FJ : 7 (Semua gaya ok, NO ANAL,

GB, CIM, CIF walaupun masih perlu diajarin hehe. namanya juga anak baru brur kan jadi lebih seru tuh sensasinya) ATT : Super GFE E Manja \& ramah udah kaya pacar sendiri

Kedua, periklanan seks. Dalam masyarakat dimana hipokretisme menggejala begitu kuat seperti di Indonesia, tumbukan-tumbukan moral akan dilihat secara ambigu, dan biasanya kesusilaan akan jauh mendapatkan perhatian. Setidaknya, dalam praktik di jalanan, kelompok-kelompok seperti Front Pembela Islam (FPI) akan jauh lebih lantang berteriak soal pakaian wanita, pelacuran, dan juga hubungan-hubungan seks 'menyimpang'. Namun, dalam pelanggaran-pelanggaran politik dan hukum seperti korupsi misalnya, mereka jauh lebih toleran. Akibatnya, represi politik baik melalui lobi dan lebih-lebih kekerasan jauh lebih kuat untuk kasus-kasus yang berhubungan dengan kesusilaan. Dalam situasi semacam ini kita tidak akan pernah menemukan praktik-praktik pelacuran terbuka setidaknya jika dibandingkan dengan Barat. Sebaliknya pelacuran akan berada dalam kondisi yang terepresi terus-menerus.

Dalam dunia cyber, menariknya, represi semacam itu tidak bisa dilakukan secara ketat. Penyebabnya karakteristik dunia cyber itu sendiri yang membuatnya hampir tak tersentuh pemegang otoritas politik dan moral sehingga pelacuran dalam dunia cyber berlangsung jauh lebih terbuka. Ini ditunjukkan oleh menguatnya 'iklaniklan' seksual yang menjajakan tubuh dan keperawanan. Dunia cyber memberikan ruang sangat besar bagi transaksi seksual yang lebih luas, pada satu sisi, dan pada saat bersamaan pemujaan akan kenikmatan hubungan seksual di sisi lain. Maraknya isu pelacuran artis kiranya tidak bisa lepaskan dari kemunculan dunia cyber ini.

Munculnya berbagai 'iklan' yang dimediasi pihak kedua atau langsung oleh si pelaku menjadi ciri khas lainnya dari wajah seksualitas dalam dunia cyber. Periklanan seks ini menceminkan lebih jauh bagaimana seksualitastidak lagi sebagai kesenangan, tapi juga komoditas. Karenanya si pemilik tubuh dan perantara mengeksploitasi seksualitas demi keuntungan material. Iklan di bawah 


\section{VIRGINTY for SELL...!!! For SERIOUS ONLY...!!!}

Mohon izin numpang buka lapak di forum ini...

KaLo ada yanG Mau beLi CeW-CEw pERAwan :

---MAsiH LuGu-LuGu

---Age between 17-22y.old (under 17th jg ada, tp peminat hrs memenuhi bbrp

kriteria/persyaratan yg ditentukan utk kenyamanan bersama)

---DijaMin masih PerAwaN (Guarantee money back)

BaLez aja Forum Ini,Ok..!!!

Harganya Relatif...

Tergantung dr kualitas (nilai face $\mathrm{n}$ body, semakin tinggi nilai nya maka semakin valuable/tinggi hrg nya).

Price Tag around 10-50 Mio (depends QUALITY)

yaNg BerMinat SERIUS, BaLez aja Thread ini.....

"BenaR-BenaR TerJamiN....."

\section{Lady available for escort service}

Hi all

Gua newbie di sini. Numpang ngasih info.

Gua Rini, tinggal di bandung, Umur 22 tahun. Gua menyediakan jasa escort service untuk makan malam, meeting, atau party.

Rate gua per malam 1,5 jt ( untuk 'service' tambahan harganya tambah 1jt) --> negotiable only if I like the guy

Bagi yang tertarik bisa lihat profile gue di situs sosial Ta**ed : Rini D Atau bisa ngontak lewat hp gua di $08782487 \mathrm{xxxx}^{1}$

Feel free to SMS or call me.

Thanks

ini yang saya ambil dari thread underground service menjadi contoh yang saya maksud.

Iklan di atas tentang penjualan keperawanan seorang gadis. Kita tidak bisa membayangkan iklan semacam ini muncul dalam media massa. Paling banter dalam kehidupan nyata, iklan-iklan itu beredar di kalangan terbatas melalui kekuatan pemasaran mulut ke mulut. Ada normanorma baik kesusilaan ataupun hukum yang masih harus diikuti dalam dunia nyata sehingga iklan semacam itu tidak akan mungkin muncul. Namun dalam dunia cyber, kaidah-kaidah moral itu dijungkirbalikkan. 
Maka ungkapan yang paling tepat untuk menggambarkannya adalah 'segalanya boleh'.

Iklan penawaran lainnya dituliskan seorang gadis yang memberikan jasa layanan ecscort seperti bisa dilihat dalam kutipan dalam box di bawah.

Iklan diatas menawarkan sebuah layanan kepadaanggota komunitas seorang gadisyang menyediakan jasa layanan escort. Meskipun iklan ini tidak memberikan gambaran fisik gadis kecuali usia, tapi orang bisa meraba tampilan dari harga yang diberikan. Selain itu, ungkapan tawaran hanya jika ia menyukai si pria mencerminkan selera yang tinggi. Sekali lagi, iklan-iklan semacam ini tidak mungkin muncul dalam dunia nyata karena masih kuatnya kaidah kesusilaan dan hukum. Namun dalam dunia cyber, kaidahkaidah hukum dan moral semacam itu telah diterabas sedemikian rupa, dan ungkapan ‘segalanya boleh' menemukan relevansinya.

\section{SIMPULAN}

Tulisan ini ingin membuktikan representasi seksualitas dalam dunia cyber. Dari paparan di atas, bisa disimpulkan bahwa seks lebih dipahami sebagai sebuah kesenangan dan komoditas. Sebagaimana telah dijelaskan sebelumnya, berbagai reportasi pelaku seksual menggambarkan bagaimana kesenangan akan hubungan seksual dipuja sedemikian rupa. Sementara di sisi lain, seiring pemujaan seksualitas sebagai kesenangan itu, adalah seks sebagai komoditas. Maka berbagai penawaran atau iklan pun menjual sebagai cara menjajakan tubuh dan seks. Orientasinya tidak lain untuk mendapatkan keuntungan-keuntungan ekonomi atas aktivitas seks yang mereka lakukan.

\section{DAFTAR PUSTAKA}

Abrahamson, Paul R. 2002. With Pleasure: Thoughts on the Nature of Human Sexuality. Oxford University Press.

Chaffee, Stephen H, dan Mirriam J. Metzger, 2001. "TheEndofMass Communication?" Mass Communication E Society. 2001. 4(4). 365-379.

Kadir, Hatib Abdul. 2007. Tangan dalam Kuasa Kelamin: Telaah Homoseks, Pekerja Seks, dan Seks Bebas di Indonesia. Yogyakarta: Insist Press.

Lievrouw, Leah A dan Sonia Livingstone (eds.), 2006. Handbook of New Media: Social Shaping and Social Consequences of ICTs. updated student edition. London Thousand Oaks. New Delhi: Sage Publications.

Winship, Janice. 2011. "Seksualitas untuk Dijual”. Dalam Stuart Hall, Dorothy Hobson, Andrew Lowe dan Paul Willis (eds.). Budaya Media Bahasa: Teks Utama Pencanang Cultural Studies 1972-1979. Yogyakarta: Jalasutra

Istiyanto, Bekti. "Menguak Konsep Diri Perempuan Pelacur di Lokasi Pariwisata Baturaden, Kabupaten Banyumas" http://sbektiistiyanto.files.wordpress. com/2008/o2/menguak-konsep-diriperempuan-pelacur.pdf

Monto, Martin A. dan Deana Julka, "Conceiving Sex as Commodity: Study of Arrested Customers of Female Street Prostitutes. Western Criminology Review 10 (1), 1-14 (2009), http://wcr. sonoma.edu/vioni/Monto.pdf

Nurhadi, "Realitas Dalam Dunia Virtual" 2006, Jurnal Atma Nan Jaya, Universitas Katolik Atma Jaya Jakarta, edisi Januari-Juni 2006, http://staff.uny. ac.id/sites/default/files/REALITAS\%20 DALAM\%20DUNIA\%2oVIRTUAL.pdf

Suriadireja, Purwadi "Seksualitas dan Ritual di Gunung Kemukus”. http://ejournal. unud.ac.id/abstrak/kemukus.pdf 